\title{
An Exploratory Fishing Survey and Biological Resource Assessment of Atlantic Hagfish (Myxine glutinosa) Occurring on the Southwest Slope of the Newfoundland Grand Bank
}

\author{
Scott M. Grant \\ Centre for Sustainable Aquatic Resources \\ Marine Institute of Memorial University of Newfoundland \\ P. O. Box 4920, St. John's, Newfoundland, Canada A1C 5R3
}

\begin{abstract}
Grant, S. M. 2006. An exploratory fishing survey and biologial resource assessment of Atlantic hagfish (Myxine glutinosa) occurring on the Southwest slope of the Newfoundland Grand Bank. J. Northw. Atl. Fish. Sci., 36: 91-110. doi: 10.2960/J.v36.m548
\end{abstract}

\begin{abstract}
An exploratory Atlantic hagfish (Myxine glutinosa) survey was conducted on the southwest slope of the Newfoundland Grand Bank during autumn 2002 to collect samples for a biological resource assessment and investigate the selective properties of baited 227-litre traps with 12.7, 13.5, and $14.3 \mathrm{~mm}(1 / 2 ", 17 / 32 "$, and 9/16") diameter escape holes. Atlantic hagfish were found to exhibit a juvenile hermaphroditic stage. Female Atlantic hagfish exhibited a total length (TL) at first, 50\%, and $100 \%$ sexual maturity of 354,378 , and $440 \mathrm{~mm}$, respectively. The testis was small and rudimentary showing no sign of maturation in the form of enlarged lobules in 350 hagfish examined within a size range of 195-638 mm TL. Each sexually mature female possessed a single clutch of developing ovoid eggs of similar size and $28 \%$ possessed both developing and degenerating eggs. Degenerating eggs were limited to the early stage of the reproductive cycle among females with developing eggs that were $<12 \mathrm{~mm}$ in length. Examination of females with large $(\geq 14 \mathrm{~mm}$ ) eggs revealed a positive correlation $\left(r^{2}=0.61\right)$ between fecundity and total body length, however, the reproductive potential was low (11-38 eggs per female). Recent evidence of a seasonal reproductive cycle and current findings of a bimodal egg length-frequency distribution and the presence of several females with postovulatory follicles in a single point in time sample suggest there may be up to three synchronized spawning events per year on the Grand Bank. The intermediate status of the Grand Bank population with respect to maximum length, size at first attainment of sexual maturity, and body markings relative to populations in the eastern North Atlantic and continental shelf and slope waters of the eastern US corroborates the existence of clinal variants. Catches in control traps indicate a clear tendency for the average individual hagfish body size to increase with depth over a 146-664 m depth range. A length-weight relationship indicated the minimum marketable body weight coincides with a total length of $410 \mathrm{~mm}$. The $14.3 \mathrm{~mm}$ trap consistently captured the lowest percentage of undersized $(<410 \mathrm{~mm}$ TL) individuals. Studies suggest few hagfish will survive when released, therefore it is recommended Grand Bank fishermen be encouraged to use traps with $14.3 \mathrm{~mm}$ escape holes or larger.
\end{abstract}

Key words: escape holes, hagfish, maturity, reproduction, survey, traps

\section{Introduction}

In the Newfoundland and Labrador region, the Atlantic hagfish (Myxine glutinosa) resource is currently at the commercial and stock assessment stage, in which emphasis is on determining whether the resource can sustain a commercially viable fishery, and to collect scientific information on which to build databases for stock assessment purposes. The primary objective of this study was to collect Atlantic hagfish from the southwest slope of the Newfoundland Grand Bank to obtain biological information necessary for making sound management decisions, with particular emphasis on the reproductive potential and elucidating the size-at-maturity. Secondary objectives included investigations into gear selectivity based on the diameter of escape holes in baited traps and whether catches warrant further investigations into the commercial potential of this resource. A detailed account of the study and its findings is preceded by a short summary of Atlantic hagfish fisheries in the western North Atlantic and current knowledge on the species distribution in the Newfoundland and Labrador region. A review of sex differentiation and the hermaphroditic stage in hagfish is also presented as a synthesis of this information provided the basis for the classification of sex and state of maturation of Atlantic hagfish. 
Fifty-nine species of hagfish are recognized globally (Fernholm, 1998). The Atlantic hagfish occurs on both sides of the North Atlantic, but grows to a larger maximum size in the western North Atlantic (Adam and Strahan, 1963; Wisner and MMillan, 1995; Martini et al., 1998). This difference in size combined with a darker body coloration, distinct markings, and greater size at first attainment of sexual maturity led Wisner and $M^{\mathrm{C} M i l l a n}$ (1995) to proposed the existence of a distinct species of hagfish (M. limosa) for the western North Atlantic. A more recent study failed to distinguish between M. limosa and M. glutinosa (Martini et al. 1998), however, the possibility that $M$. limosa is a clinal variant of M. glutinosa was not ruled out (Fernholm, 1998; Martini et al., 1998).

Historically, the Atlantic hagfish was of no commercial importance in Canada, but has recently come under consideration in coastal waters of Nova Scotia and New Brunswick and studies into its commercial potential have also been carried out in the Newfoundland and Labrador region (DFO, 1993, 1998; TriNav, 1996). Hagfish have been utilized in diverse ways, ranging from a source of food for human consumption to a light leather substitute, and a cleanser has been made from the slime (Honma, 1998). Currently, hagfish are utilized for their skin and meat with Korea being the major importer. In the Pacific Ocean, hagfish are typically captured using a small ( 20 litre) baited Korean style trap and 136-litre plastic barrels fitted with one-way entrance funnels from Korean traps have proven to be a successful method of capturing Atlantic hagfish in the Newfoundland and Labrador region (DFO, 1993; TriNav, 1996). Preliminary trapping studies conducted off the southwest coast of insular Newfoundland indicated an abundance of Atlantic hagfish, but many were below market size (TriNav, 1996). Given the difficulties associated with sorting and live release of undersized individuals from the catch, it was suggested future studies investigate gear selectivity methods such as increasing the size of escape holes to $14.3 \mathrm{~mm}(9 / 16 ")$ or more, and expanding the survey area to deep (>183-256 m) water (TriNav, 1996).

There is no available scientific information on which to base a minimum legal size in Atlantic hagfish fisheries. As such, the minimum size is currently based on market demands. In Atlantic Canada, there has been considerable variability in the reporting of minimum market size of Atlantic hagfish based on total body length. This may in part be attributed to varying market demands resulting from over fishing and yearly fluctuations in the availability of large hagfish in Atlantic and
Pacific Ocean fisheries. In the early 1990s, Atlantic hagfish fisheries were established in the Gulf of Maine where fishermen have been reported to use traps with $9.5 \mathrm{~mm}\left(3 / 8^{\prime \prime}\right)$ diameter escape holes and processors have accepted hagfish as small as $350 \mathrm{~mm}$ TL (Martini et al., 1997a, 1997b; AHWG, 2003). As a conservation measure, the minimum size was raised to $510 \mathrm{~mm}$ TL after two years of harvesting, however, evidence of localized depletion and declines in landings, average individual size, and catch-per-trap suggest the Gulf of Maine hagfish fishery is not sustainable (Martini et al., 1997b; Martini, 1998a; AHWG, 2003; NEFSC 2003). Increasing the minimum size did not appear to have the desired effect as fishermen still continue to use traps with small escape holes, which appears to have resulted in at-sea discard rates of as much as 70\% (Martini et al., 1997b; AHWG, 2003). High discard rates and evidence of little chance of hagfish surviving when released at the surface led Martini (1998a) to emphasize the need for trap studies on an appropriate escape hole size to reduce over fishing of juveniles and non-market sized hagfish. According to Martini (1998a), the minimum size suitable for leather production is $500 \mathrm{~mm}$ total length. The minimum size the Korean market currently demands for consumption is based on individual body weight (80 $\mathrm{g}$ in 2002; R. Quinlan, Quinlan Brothers Ltd, St. John's NL, pers. comm.) and in the absence of information on size-at-maturity, marketable body weight should be taken into consideration when assessing gear selectivity in a management region.

Little is known about the distribution or abundance of Atlantic hagfish in the Newfoundland and Labrador region. Fisheries and Oceans Canada bottom trawl surveys indicate a distribution within the Esquiman and Laurentian channels of the Gulf of St. Lawrence, the Hermitage Channel on the south coast of insular Newfoundland, and the southwest slope of the St. Pierre and Grand Banks (Fig. 1). Limited information on distribution and abundance is largely related to the burrowing and general immobile behaviour of Atlantic hagfish (Martini, 1998b), which reduces their vulnerability to groundfish surveys. Anecdotal evidence of Atlantic hagfish scavenging in gillnet fisheries suggests this species is common along the south coast of insular Newfoundland, from Codroy eastward to Harbour Breton and trapping studies demonstrate an abundance in coastal areas (DFO, 1993; TriNav, 1996). Preliminary trapping studies have reported individual trap catches of over 60 individuals per trap night (DFO, 1993) and an exploratory fishery conducted in NAFO Subdiv. 3Pn reported catches in the hundreds (TriNav, 1996). Gillnet fishermen have also provided 


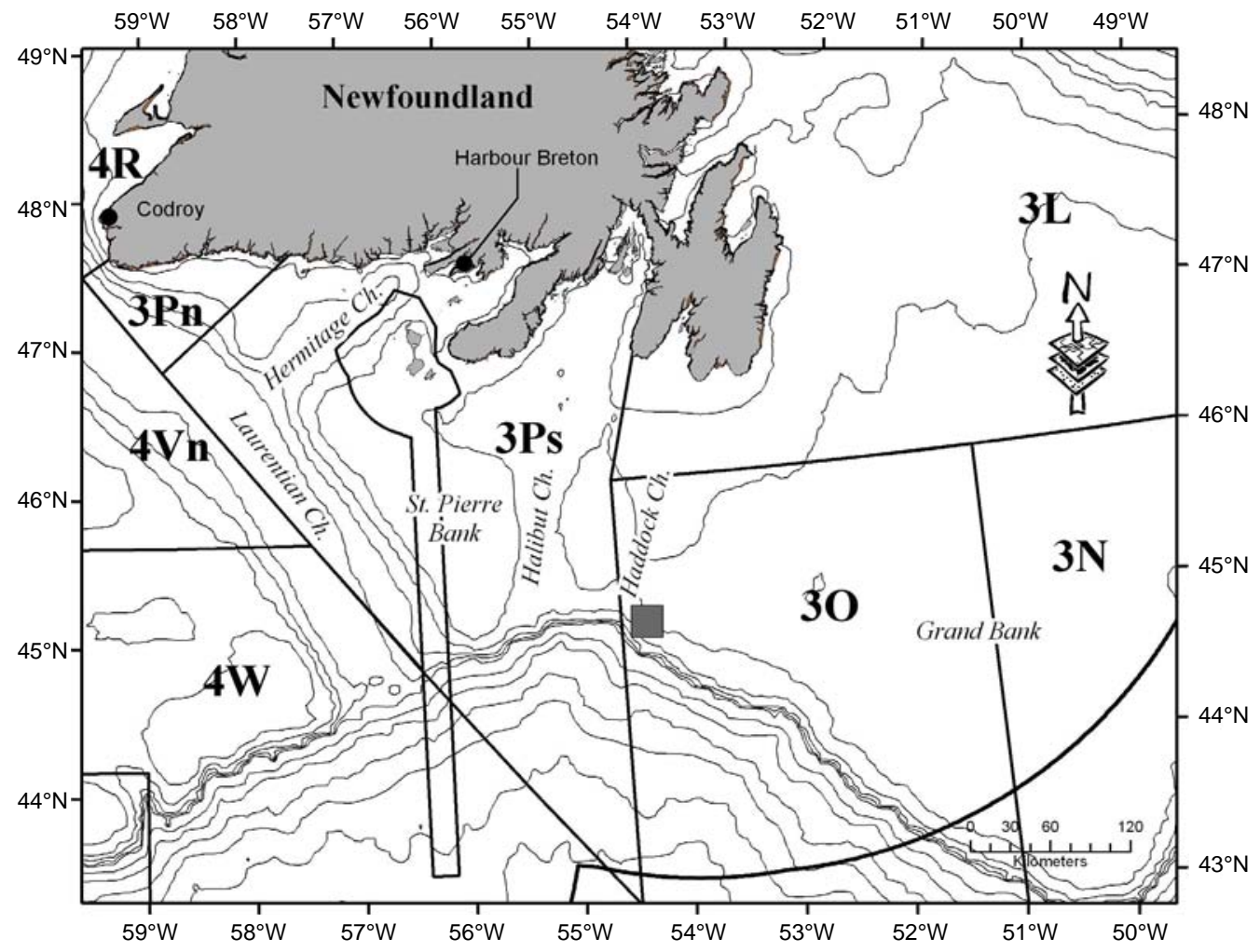

Fig. 1. The Grand Bank showing the survey area (embossed square), locations referenced in text, bathymetry, and NAFO Divisions.

anecdotal evidence that Atlantic hagfish are abundant in offshore waters on the slope of the St. Pierre and Grand banks, which coincides with the distributions described by bottom trawl surveys.

Much of the biology of hagfishes is poorly understood. Even the most basic aspects of hagfish life history, including growth rate, age-at-sexual maturity, and longevity, remains a mystery, as there is no known method of aging hagfish (Honma, 1998; Martini, 1998b). Hagfish do not possess scales for aging and the skeletal system is comprised entirely of cartilage. Sex differentiation and reproduction are the most studied aspects of hagfish life history and were heavily influenced over a century ago (1864) when the Academy of Science of Copenhagen offered a prize for a solution to the method of reproduction of Myxine.

Hagfish are not functional hermaphrodites, but sexually mature individuals possess rudimentary or degenerated gonadal tissue of the opposite sex (Walvig, 1963; Gorbman, 1990; Patzner, 1998). Historically, there was some confusion regarding sex differentiation and state of sexual maturity in hagfish. Some of the earliest studies of Atlantic hagfish described the species as a protan- dric hermaphrodite (Cunningham, 1886; Nansen, 1887) with the male elements of the gonad maturing to spawn first followed by the female elements, and Cunningham (1886) even suggested self-fertilization during the hermaphroditic phase. After a more thorough examination, Schreiner (1955) concluded that Atlantic hagfish enter a juvenile hermaphroditic stage, which is followed by the selective degeneration of one of the developing sexual elements, leaving a functional ovary in the anterior region of the gonad in adult females or a functional testis posteriorly in adult males. Two forms of sterility have been described for Atlantic hagfish: in the first instance neither a testis nor an ovary develop; while in the second, both the testis and ovary develop abnormally and exhibit degenerative traits due to a mingling of the ovarian and testicular tissues (Schreiner, 1955; Walvig, 1963; Patzner, 1998).

Gorbman (1990) conducted a detailed analysis of sex differentiation in the Pacific hagfish (Eptatretus stouti), which showed the anterior region of the gonad developed first, beginning with development of the germinal epithelium, followed by the development of oocysts and small $(\geq 0.06 \mathrm{~mm})$ clear oocytes. If the individual was to become a female, the oocytes continued to 
develop eventually entering the vitellogenic or yolk formation stage and the posterior or male component of the gonad remained indifferent. If on the other hand, it was to become a male, testicular follicles began to develop in the posterior region of the gonad, while the germinal epithelium of the ovary and oocytes generally degenerated until the ovary was comprised of a dense connective tissue core and numerous blood vessels. Gorbman (1990) considered the sequence of gonadal development in Pacific hagfish to represent progynous hermaphroditism and concluded that in males, there is typically a temporary form of juvenile hermaphroditism.

Atlantic hagfish do not appear to exhibit a definitive spawning season in the North Atlantic, rather they seem capable of spawning throughout the year (Cunningham, 1886; Nansen, 1887; Walvig, 1963; Patzner, 1998). The testis in adult males that are maturing to spawn is comprised of several well-developed lobules containing the testicular follicles (Walvig, 1963; Patzner, 1998). Ovary development begins with an enlargement of the genital ridge to form the germinal epithelium, which is followed by the development of small clear oocytes (Schreiner, 1955; Walvig, 1963). When the eggs reach a diameter of about 1-2 $\mathrm{mm}$ they may stop growing and enter a resting period (Walvig, 1963). The resting period may be short in first time spawners or last until the preceding generation of eggs is ovulated in repeat spawners. When the resting eggs resume development they begin to accumulate yolk and take on the characteristic ovoid shape at a diameter of about 2-3 mm (Walvig, 1963; Patzner, 1998). The length of fully mature eggs at ovulation varies from 14-25 mm and may be identified by the presence of anchor-filaments at both ends (Walvig, 1963; Scott and Scott, 1988; Patzner, 1998). The duration of the reproductive cycle is unclear (Powell et al., 2004), however, a low rate of reproduction (fecundity) has been well documented. Scott and Scott (1988) indicate female Atlantic hagfish may possess from one to 30 eggs and Patzner (1998) reported 6-32 eggs per female per reproductive cycle. Fully mature eggs are ovulated into the body cavity prior to spawning, pass through the cloaca, and appear to be fertilized externally (Walvig, 1963; Patzner, 1998).

\section{Methodology}

\section{Exploratory Fishing Survey}

During late autumn 2002, two exploratory fishing trips were conducted on the southwest slope of the Grand Bank near the confluence of the Haddock Channel, NAFO Div. $3 O$ (Fig. 1). Choice of survey area was based on traditional ecological knowledge of gillnet fishermen.
The survey encompassed four depth intervals: $146 \mathrm{~m}$, 245-293 m, 384-454 m, and 591-664 m. The $146 \mathrm{~m}$ depth interval was sampled from 21-22 November while the remaining depth intervals were sampled from 30 November to 3 December. The fishing and sampling platform was the Covenant II, a $19.8 \mathrm{~m}$ commercial fishing vessel. Fishing was conducted using 227-litre plastic barrels fitted with four one-way entrance funnels used in Korean hagfish traps. Each funnel had an entrance diameter of $50 \mathrm{~mm}$ and contained flexible collapsing teeth that prevented hagfish from escaping back through the entrance. Two entrance funnels were located on each side of a trap and approximately 125 escape holes were drilled in the sides and ends. Each trap was baited with $1-1.5 \mathrm{~kg}$ of frozen herring and mackerel without bait protection. For experimental purposes, a control trap with $3.2 \mathrm{~mm}\left(1 / 8^{\prime \prime}\right)$ diameter drainage/flood holes and three test traps with escape hole sizes of $12.7,13.5$, and $14.3 \mathrm{~mm}\left(1 / 2^{\prime \prime}, 17 / 32^{\prime \prime}\right.$, and 9/16") diameter were fished at each depth interval. Test trap escape holes also served as drainage/flood holes. The experimental procedure consisted of randomly assigning three of each of the control, and $12.7,13.5$, and $14.3 \mathrm{~mm}$ test traps to locations in a long line fleet with 18 additional $14.3 \mathrm{~mm}$ traps for a total of 30 traps. All traps were spaced at about $37 \mathrm{~m}$ intervals and fished on the bottom for at least $24 \mathrm{hrs}$.

\section{Analysis of the Catch}

Catch-per-unit effort was assessed for the control and experimental traps. During the first trip, capture rates were high in the control and $12.7 \mathrm{~mm}$ traps. High capture rates in conjunction with excessive secretion of slime and high activity levels of hagfish resulted in handling difficulties. Consequently, during the first trip, hagfish counts were limited to a single trap in each of the control and test traps. During the second trip, individual counts were carried out on catches in each of the three test traps, but catches in a single control trap were estimated by volumetric sampling.

Up to 250 hagfish were randomly sampled from each trap type. Hagfish were frozen at sea and later thawed in the laboratory to obtain individual measurements of total length (TL; $\pm 1 \mathrm{~mm}$ ) and blotted wet body weight $( \pm 0.1 \mathrm{~g})$. These data were $\log _{10}$ transformed and used to derive length-weight relationships by method of least squares regression. Intercept values were back transformed so as to present the equations in their curvilinear form. Once individual length and weight measurements were obtained, each sample was preserved in 10\% formalin. After six months, a subsample of 275 individuals representing the size range of hagfish captured was selected from the formalin preserved samples to obtain 
information on the sex, state of sexual maturity, and fecundity. The method of least squares regression was used to determine the relationship between fecundity and total body length. These data were $\log _{10}$ transformed for the analysis.

Sex and maturity were determined by dissection of the body cavity and examination of the gonad by naked eye, dissection microscope $(10 \times)$, or slide mounts $(40 \times)$ where necessary. Developing ovoid eggs were counted for sexually mature females. Observations revealed that a single clutch size of ovoid eggs was developing in each sexually mature female and vernier caliper/ocular micrometer length measurements $( \pm 0.1 \mathrm{~mm})$ on developing eggs of 20 females indicated little difference $(0.1-0.8 \mathrm{~mm})$ in length within an individual female. Therefore, a length measurement was conducted on a single representative developing egg for the remaining sexually mature females. Degenerated eggs were counted and total length measured. Degenerated eggs were noticeably smaller, pale white, irregularly shaped or collapsed, and generally exhibited a more proximal location to the ovary than developing eggs (Walvig, 1963).

\section{Results}

\section{Sex, Maturity, and Body Coloration}

Hagfish were preserved in $10 \%$ formalin prior to analysis of sexual maturity. $\mathrm{M}^{\mathrm{C}}$ Millan and Wisner (1984) indicate length of time in preservative significantly affects total length in hagfish and shrinkage of $10 \%$ is not uncommon. In the current study, samples remained in formalin for six months, therefore, a $10 \%$ correction factor has been added to all total length measurements presented for formalin preserved hagfish.

A total of 275 Atlantic hagfish ranging from 195 to $638 \mathrm{~mm}$ TL were examined for sex and state of maturation. All hagfish $\leq 246 \mathrm{~mm}$ TL showed no sign of gonadal differentiation. Juvenile gonad differentiation appeared progynous, with the ovarian component enlarging first in $7 \%$ of the hagfish examined. These hagfish ranged from 248-336 mm TL, possessed an early developing ovary, and exhibited no evidence of a developing testis (Fig. 2). The smallest individual to exhibit a differentiated testis was $290 \mathrm{~mm}$ TL and a developing ovary accompanied a developing testis in all but one juvenile measuring $350 \mathrm{~mm}$ TL. Generally, once hagfish attained a size of $360 \mathrm{~mm}$ TL they were found to possess both a small, solid, and round testis posteriorly and an ovary comprised of germinal tissue of varying thickness with clear oocytes or developing opaque eggs anteriorly. In the current study, when an individual was found to possess a rudimentary testis and/or an ovary with small and clear oocytes the sex was considered to be indeterminate since at these early stages of development Atlantic hagfish still have the capacity to become either a functional male or female (Schreiner, 1955; Gorbman, 1990). This coincides with the juvenile hermaphroditic stage Schreiner (1955) described for this species. Atlantic hagfish that possessed opaque and round eggs in the ovary were considered to be immature females and individuals possessing opaque ovoid eggs were considered to be adult females maturing to spawn.

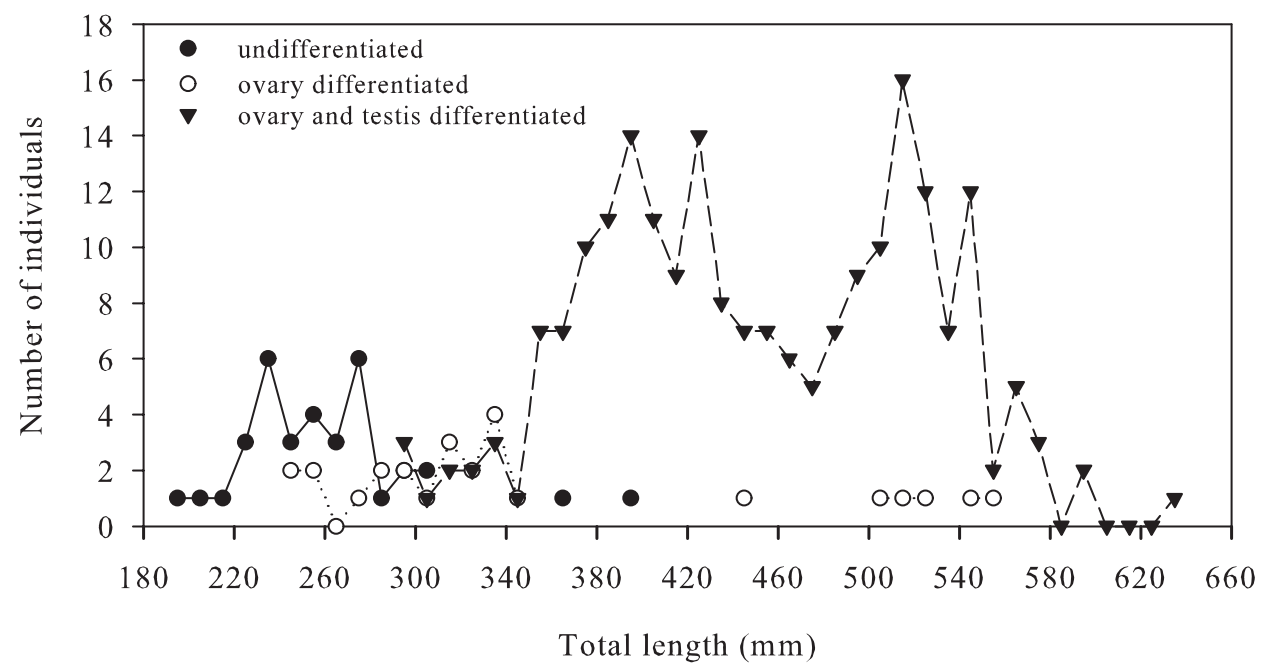

Fig. 2. Gonadal differentiation in Atlantic hagfish $(n=275)$. The testis was reduced in size or absent in adult females. 
In all hagfish examined, the testis was small and rudimentary and showed no sign of maturation in preparation for spawning in the form of enlarged lobules. Further, males could not be definitively distinguished during a cursory dissection and examination of the gonad in an additional 75 hagfish $\geq 220 \mathrm{~mm}$ TL. Total length of the smallest immature female, based on the presence of $0.7 \mathrm{~mm}$ opaque and round eggs, was $292 \mathrm{~mm}$. The smallest adult female exhibited a total length of $354 \mathrm{~mm}$ and possessed 15 well-developed ovoid eggs that were $15.3 \mathrm{~mm}$ in length. Adult females did not appear to be in spawning condition as no ovulated eggs or eggs with anchor-filaments were found in the body cavity. However, the ovary of 24 adult females was found to possess postovulatory follicles of similar length $(2.8-6.8 \mathrm{~mm})$. The ovary of two additional adult females possessed both postovulatory follicles and a single large (18.0 and $22.0 \mathrm{~mm}$ ) degenerated egg. These large degenerated eggs were collapsed, irregularly shaped, and still bound within the follicle. The next clutch of eggs was developing in 15 females with postovulatory follicles. These eggs were ovoid and ranged from $2.5-7.5 \mathrm{~mm}$ in length. An independent-samples t-test indicated there was no significant difference in length between females that possessed both postovulatory follicles and developing ovoid eggs and females that possessed only postovulatory follicles $\left(t_{23}=0.61, P=0.545\right)$.

There was no conclusive evidence of sterility in the Grand Bank Atlantic hagfish population. Two moderate sized hagfish (369 and $397 \mathrm{~mm}$ TL) showed no gonadal development (Fig. 2) but were within the juvenile size range (Fig. 3).
A Gompertz curve provided a good fit $\left(r^{2}=0.982\right.$, $\left.F_{37}=671.4, P<0.0001\right)$ to the female percent maturity data (Fig. 3). From this analysis it was determined 50\% of the females attain sexual maturity at about $378 \mathrm{~mm}$ TL (Fig. 3). Adult females dominated the sample, comprising $64 \%$ of the 275 fish examined, and all hagfish exhibiting a total length of $440 \mathrm{~mm}$ or greater were adult females. The testis was still present in all but six large (>440 mm TL) adult females (Fig. 2). In the remaining adult females, the testis had undergone a reduction in size compared to that observed among individuals in which sex was classified as indeterminate.

As was previously stated, each adult female was found to possess a single clutch of developing ovoid eggs, all of similar size. A plot of the frequency distribution of egg length among 150 sexually mature females ranging from $354-595 \mathrm{~mm}$ TL illustrates that state of egg development varied widely within the Grand Bank population (Fig. 4). The distribution is bimodal with some females possessing small to moderate sized eggs in early stages of development, while others possessed large eggs that were within the documented size range (14-25 mm) of eggs at ovulation (Walvig, 1963; Patzner, 1998). There was no correlation $\left(r^{2}<0.05 ; P>0.05\right)$ between egg length and body length among females from the small $(2.8-13.8 \mathrm{~mm})$ or large $(14-23 \mathrm{~mm})$ egg length mode.

The number of developing eggs per female (fecundity) was assessed for 98 Atlantic hagfish. Fecundity ranged from 11-49 (average, $26.0 \pm 8.7$ STD) eggs per female and there was a weak correlation between

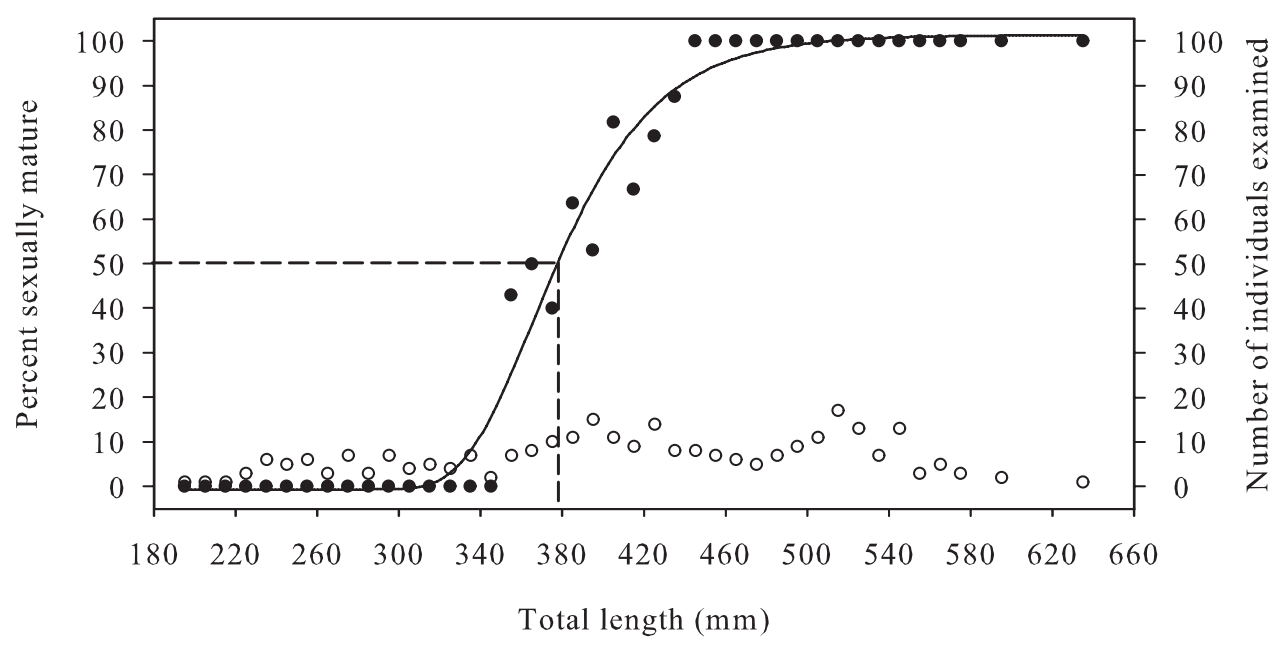

Fig. 3. Percent maturity ogive (solid symbols and solid line) for female Atlantic hagfish. The approximate length at $50 \%$ maturity $(378 \mathrm{~mm}$, dashed vertical line) is illustrated. The number of fish examined within each $10 \mathrm{~mm}$ length-class (open symbols) is also shown. 


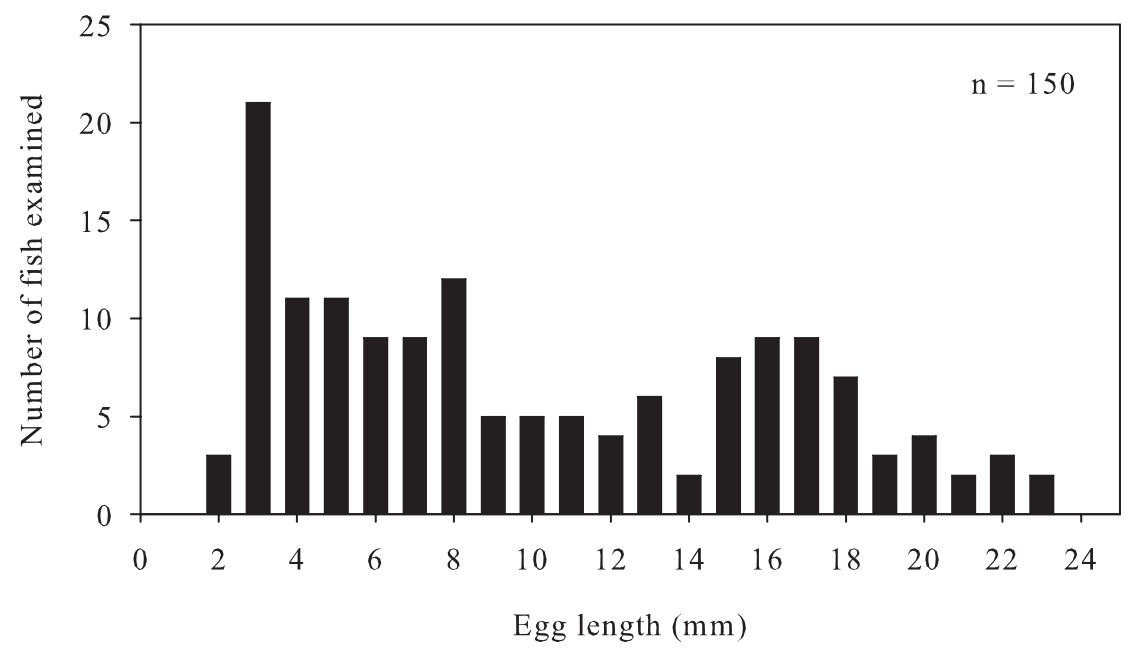

Fig. 4. Atlantic hagfish egg length-frequency distribution. The total number of adult females examined $(n)$ is indicated.

fecundity and body length $\left(r^{2}=0.221, F_{97}=26.91\right.$, $P<0.0001)$. However, egg length was variable among these females, ranging from 4.7-22.4 mm, and Lyngnes (1936) indicated that as the eggs of eastern North Atlantic hagfish grow the total number decreases by about half as a result of degeneration and resorption. Lyngnes (1936) also found the degeneration percentage is fairly similar and high among eggs that are 2-17 $\mathrm{mm}$ long, and then decreases among larger eggs. Therefore a fecundity-body length relationship was also derived for 22 hagfish ranging from $377-572 \mathrm{~mm}$ TL that possessed eggs $\geq 17 \mathrm{~mm}$ in length. Fecundity ranged from 11-32 (average, $21.4 \pm 1.2 \mathrm{STD}$ ) among these hagfish and there was a moderate correlation between fecundity and body length $\left(r^{2}=0.444, F_{21}=15.94, P=0.0007\right)$. The curvilinear relationship was described by the following equation: fecundity $=0.0004 \mathrm{TL}^{1.77}$. A fecundity-body length relationship was also derived for 43 hagfish that possessed eggs $\geq 14 \mathrm{~mm}$ in length, the minimum documented length at ovulation (Walvig, 1963). Fecundity ranged from 11-38 (average 22.0, \pm 5.9 STD), TL ranged from $354-572 \mathrm{~mm}$, the correlation improved $\left(r^{2}=0.616, F_{42}\right.$ $=65.72, P<0.0001)$, and the equation was identical to that derived for 22 animals with eggs $\geq 17 \mathrm{~mm}$; fecundity $=0.0004 \mathrm{TL}^{1.77}$.

A detailed examination of the ovary of 53 females that possessed developing eggs from 4.7-20.6 mm in length revealed that 15 individuals $(28 \%)$ possessed eggs that could be characterized as degenerating (Walvig, 1963). Degenerating eggs were not found in females that possessed developing eggs $\geq 12.4 \mathrm{~mm}$ in length. Degenerating eggs represented 3-29\% (average, 17.0\%) of the total fecundity (TL); number of degenerating and developing eggs. Total fecundity ranged from 26 to 63 and there was a strong $\left(r^{2}=0.70\right)$ and positive correlation between total fecundity and the number of degenerating eggs (Fig. 5). When females with degenerating eggs were considered, there was no correlation $\left(r^{2}<0.05\right)$ between length of the developing eggs and number of degenerating eggs or length of the developing eggs and total fecundity.

All Atlantic hagfish examined in the current study exhibited a uniform grayish-pink body coloration, similar to that described for animals collected in the eastern North Atlantic (Wisner and MCMillan, 1995). Formalin preserved animals were also observed to retain this body coloration after being held in white plastic buckets for over two years. Examination of a random sample of 100 formalin preserved individuals ranging in size from 251-550 $\mathrm{mm}$ TL revealed the presence of a narrow and pale streak along the dorsal midline extending forward from the caudal finfold in $93 \%$ of the animals. The streak extended an average of $14.9 \%$ of the TL (range $3.2-49.4 \%$ ). Removal of the skin suggested the streak was associated with a band of connective tissue, similar to that reported by Wisner and MCMillan (1995).

\section{Length-Weight Relationships and Minimum Mar- ketable Body Length}

Total length was a good predictor of body weight in Atlantic hagfish captured at both the 384-457 $\mathrm{m}$ and 591-664 $\mathrm{m}$ depth intervals. There were no hagfish collected from the 245-293 $\mathrm{m}$ depth interval (see below) and measurements of body weight were not performed 
on hagfish collected from the $146 \mathrm{~m}$ site. An analysis of covariance (GLM, SPSS) indicated the slopes and elevations of the regression lines did not differ significantly with depth (slope, $F_{1,1782}=0.057, P=0.811$; elevation, $\left.F_{1,1781}=0.111, P=0.675\right)$, therefore the data were combined (Fig. 6). The equation derived from the two relationships (Fig. 6) indicates the current minimum marketable body weight $(80 \mathrm{~g})$ coincides with a total length of
$410 \mathrm{~mm}$. According to the maturity ogive (Fig. 3), about $80 \%$ of the females in the Grand Bank population will have attained sexual maturity by the time they grow to market size. Throughout the remainder of this report, Grand Bank Atlantic hagfish $<410$ mm TL are considered undersized, as they are unsuitable for leather production $(<500 \mathrm{~mm}$ TL) and unsuitable for consumption $(<80 \mathrm{~g})$.

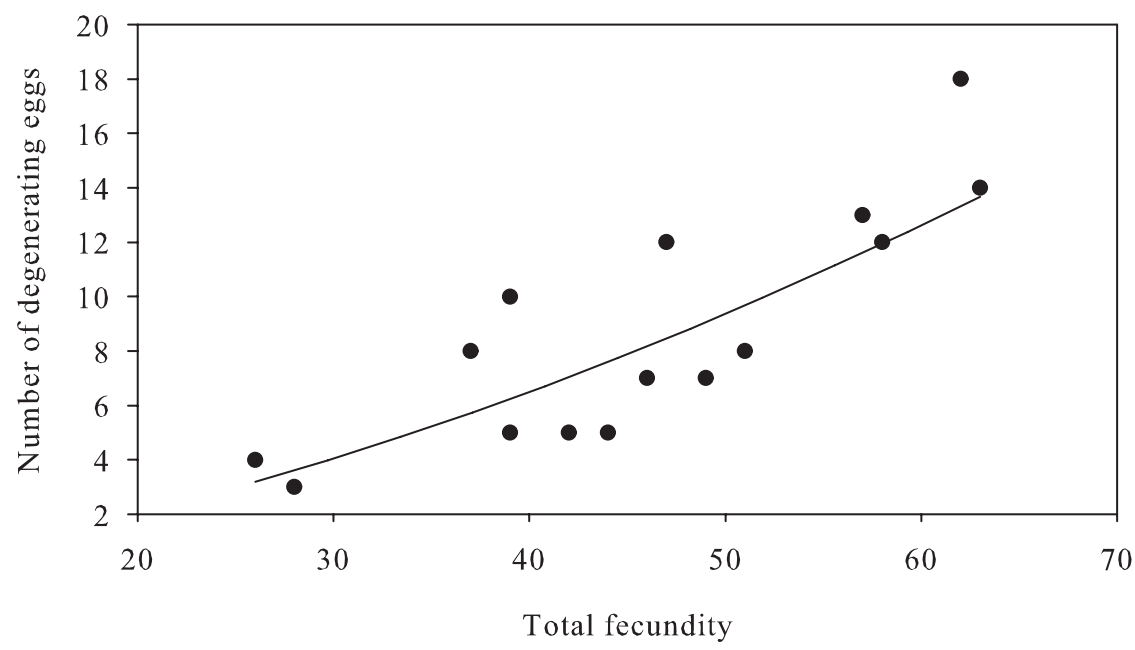

Fig. 5. Degenerating egg-total fecundity (developing and degenerating eggs) relationship for Grand Bank Atlantic hagfish.

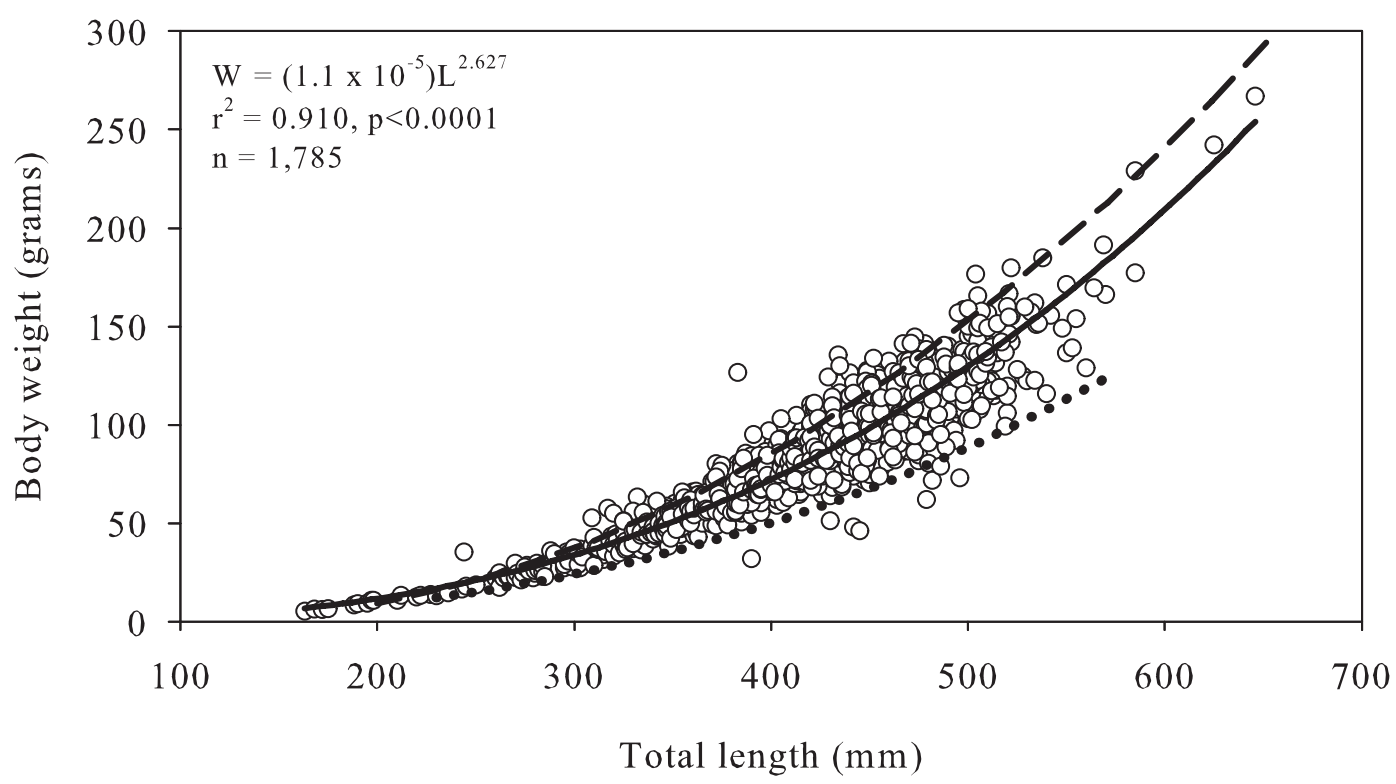

Fig. 6. Length-weight relationship for Grand Bank Atlantic hagfish illustrating the line of best fit (solid line) and corresponding equation ( $W=$ weight, $L=$ total length, $r^{2}=$ correlation coefficient, $p=$ probability level, and $n=$ number of fish examined). Two lines representing equations derived for Gulf of Maine Atlantic hagfish are also illustrated (dashed line: $n=80$, Martini et al., 1997a; dotted line: $n=49$, AHWG, 2003). 
Lines representing two equations derived for lengthweight data from Atlantic hagfish captured in the Gulf of Maine (Martini et al., 1997a; AHWG, 2003) appear to encompass the line of best fit derived for the Grand Bank population (Fig. 6). However, the equation presented by Martini et al. (1997a) is erroneous, as it does not agree with the length-weight relationship and line of best fit illustrated in Fig. 1 of their manuscript. Their pictorial representation of the relationship does however agree with the relationship and corresponding equation presented in a more recent report on the status of New England Atlantic hagfish fisheries (AHWG, 2003), which when compared to the Grand Bank population (Fig. 6) indicates the existence of much thinner and overall longer animals that do not attain market size $(80 \mathrm{~g})$ until they grow to about $485 \mathrm{~mm}$ TL. Processors and harvesters alike have also commented on the smaller maximum length and greater weight at length of Grand Bank Atlantic hagfish when compared to hagfish harvested from the New England region, which includes the Gulf of Maine. The Grand Bank relationship is based on a relatively large number of observations compared to previous studies in the western North Atlantic (Martini et al., 1997a; AHWG, 2003) and indicates substantial variability in weight at length, particularly in larger fish (Fig. 6). For example, 169 individuals examined within the 440-449 mm length-class exhibited a range in weight of 76.6-127.7 g. Spawning condition and egg size of females account for some of the variability as an analysis of the gonadosomatic index of 30 mature females $\geq 380 \mathrm{~mm}$ TL from the Grand Bank population revealed the gonad accounted for $<1-20 \%$ of total body weight.

\section{Catch Rates and Length-Frequency Distributions}

Experimental trap line soak times ranged from 24.5-50.0 hr (Table 1). The 50-hour soak time at the 245$293 \mathrm{~m}$ depth interval resulted in the catch being too badly decomposed to obtain individual counts or representative measurements of body length. Inclement weather prevented these traps from being hauled sooner. The trap contents consisted of a large mass of slime and dead rotting hagfish. The slime was so profuse that it blocked the escape holes preventing the drainage of water, which made the traps very difficult to handle when hauled on board. The most likely cause of death was suffocation from an excessive secretion of slime. The entire catch was dumped overboard. Although the number of dead individuals was not quantified during this study, dead hagfish were also observed in the control traps at all observed soak times and dead hagfish were found in the $12.7 \mathrm{~mm}$ and $13.5 \mathrm{~mm}$ test traps when the catches in a trap were high $(\geq 900)$. All dead hagfish were found encased in a mass of slime.

Catches in the control traps were always considerably higher than those of the test traps indicating hagfish were utilizing the escape holes provided (Table 1). Body

TABLE 1. Atlantic hagfish catch (number of fish) summary by trap type and depth interval. Mean catches ( \pm one standard deviation) are also shown where available.

\begin{tabular}{|c|c|c|c|c|c|c|}
\hline \multirow[b]{2}{*}{ Date } & \multirow[b]{2}{*}{ Depth (m) } & \multirow[b]{2}{*}{$\begin{array}{l}\text { Soak time } \\
\text { (hours) }\end{array}$} & \multirow[b]{2}{*}{ Control } & \multicolumn{3}{|c|}{ Trap type } \\
\hline & & & & $\begin{array}{c}12.7 \mathrm{~mm} \\
\text { escape holes }\end{array}$ & $\begin{array}{c}13.5 \mathrm{~mm} \\
\text { escape holes }\end{array}$ & $\begin{array}{c}14.3 \mathrm{~mm} \\
\text { escape holes }\end{array}$ \\
\hline $21 \mathrm{Nov}$ & 146 & 24.5 & 4401 & 3198 & 1200 & 230 \\
\hline $27 \mathrm{Nov}$ & $245-293$ & 50.0 & Decomposed & Decomposed & Decomposed & Decomposed \\
\hline \multirow[t]{2}{*}{$01 \mathrm{Dec}$} & $384-457$ & 33.0 & 2040 & $\begin{array}{c}256 \\
80 \\
921\end{array}$ & $\begin{array}{c}149 \\
50 \\
106\end{array}$ & $\begin{array}{c}222 \\
83 \\
116\end{array}$ \\
\hline & & & Mean & $\begin{array}{c}419.0 \\
( \pm 443.6)\end{array}$ & $\begin{array}{c}101.7 \\
( \pm 49.6)\end{array}$ & $\begin{array}{c}140.3 \\
( \pm 72.6)\end{array}$ \\
\hline \multirow[t]{2}{*}{$03 \mathrm{Dec}$} & $591-664$ & 34.5 & 3373 & $\begin{array}{c}107 \\
36 \\
116\end{array}$ & $\begin{array}{c}144 \\
135 \\
66\end{array}$ & $\begin{array}{c}159 \\
59 \\
148\end{array}$ \\
\hline & & & Mean & $\begin{array}{c}86.3 \\
( \pm 43.8)\end{array}$ & $\begin{array}{c}115.0 \\
( \pm 42.7)\end{array}$ & $\begin{array}{c}122.0 \\
( \pm 54.8)\end{array}$ \\
\hline
\end{tabular}




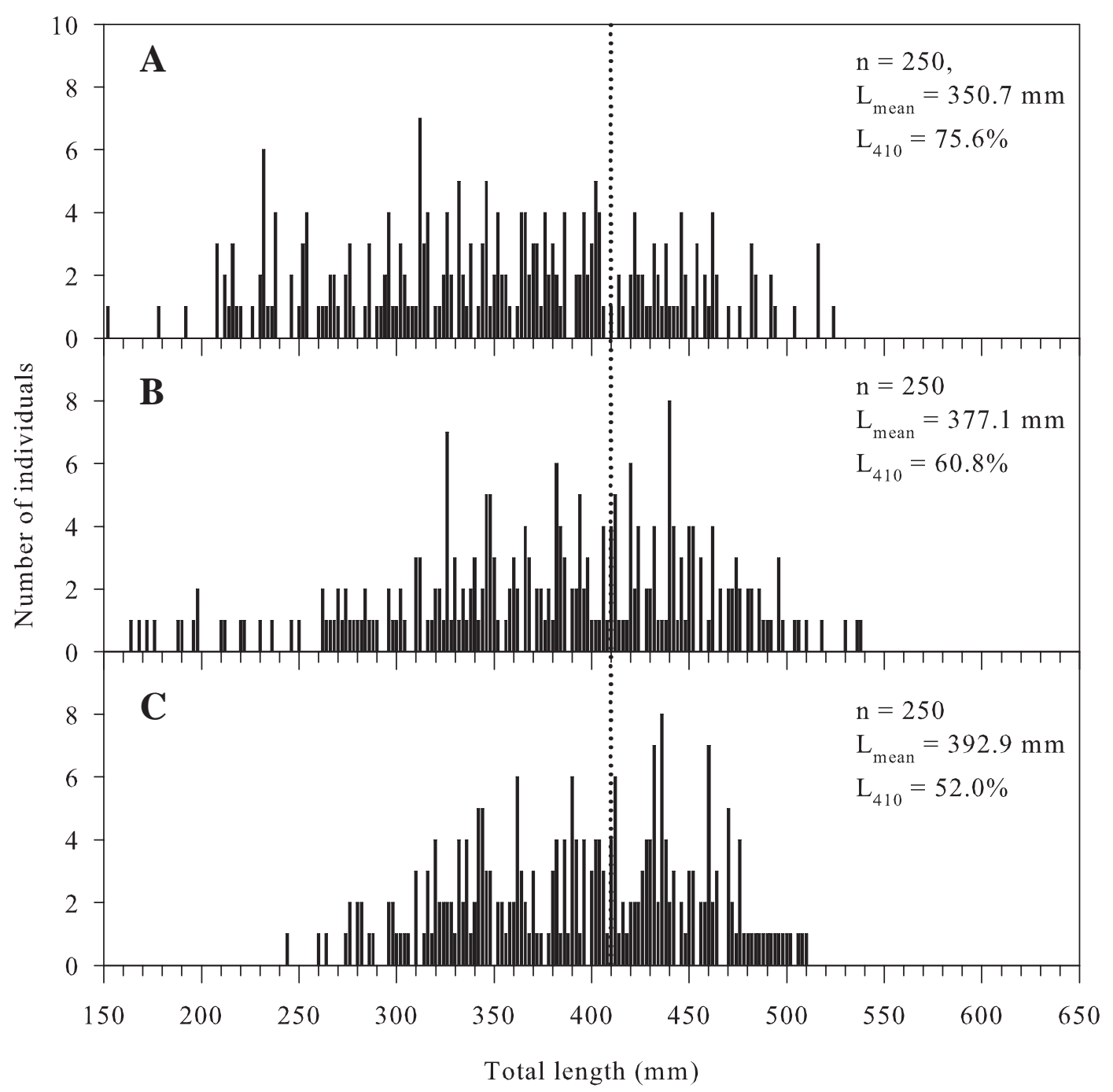

Fig. 7. Atlantic hagfish length-frequency distributions in control traps fished at depth intervals of (A) $146 \mathrm{~m}$, (B) 384-457 m, and (C) 591-664 m on the southwest slope of the Grand Bank. The dotted vertical line represents the minimum marketable body length $(410 \mathrm{~mm})$. Number of fish examined $(n)$, mean total length $\left(L_{\text {mean }}\right)$, and the proportion of undersized individuals $\left(L_{410}\right)$ are illustrated in each panel.

size in the control traps ranged from $153-538 \mathrm{~mm}$ TL (Fig. 7). There was a depth related increase in average individual body length in the control traps, which coincided with a reduction in the percentage of small juveniles and undersized individuals (Fig. 7). A one-way analysis of variance indicated the average body length differed significantly among the depth intervals sampled $\left(F_{2} ; 747=21.55, P<0.0001\right)$ and a post hoc test of truly significant differences (Games-Howell) revealed a significant increase in average body length with each increase in depth $(146 \mathrm{~m} \times 384-457 \mathrm{~m}, P=0.001 ; 146$ $\mathrm{m} \times$ 591-664 $\mathrm{m}, P<0.0001 ; 384-457 \mathrm{~m} \times 591-664 \mathrm{~m}$, $P=0.031)$. Thus, there was a clear tendency for the average individual body length and hence weight (Fig. 6) to increase with increasing depth. There were no distinct length-classes to infer population age structure in the control trap length-frequency distributions (Fig. 7).

Although the catches were only recorded in one of the $12.7,13.5$, and $14.3 \mathrm{~mm}$ test traps set at the $146 \mathrm{~m}$ depth interval, there was evidence of a substantial reduction in the catch with each increase in escape-hole size (Table 1). Length-frequency distributions (Fig. 8) also illustrate a substantial reduction in the catch of juveniles and undersized hagfish with each increase in escapehole size. A one-way analysis of variance indicated a 
GRANT: Hagfish on the Newfoundland Grand Bank

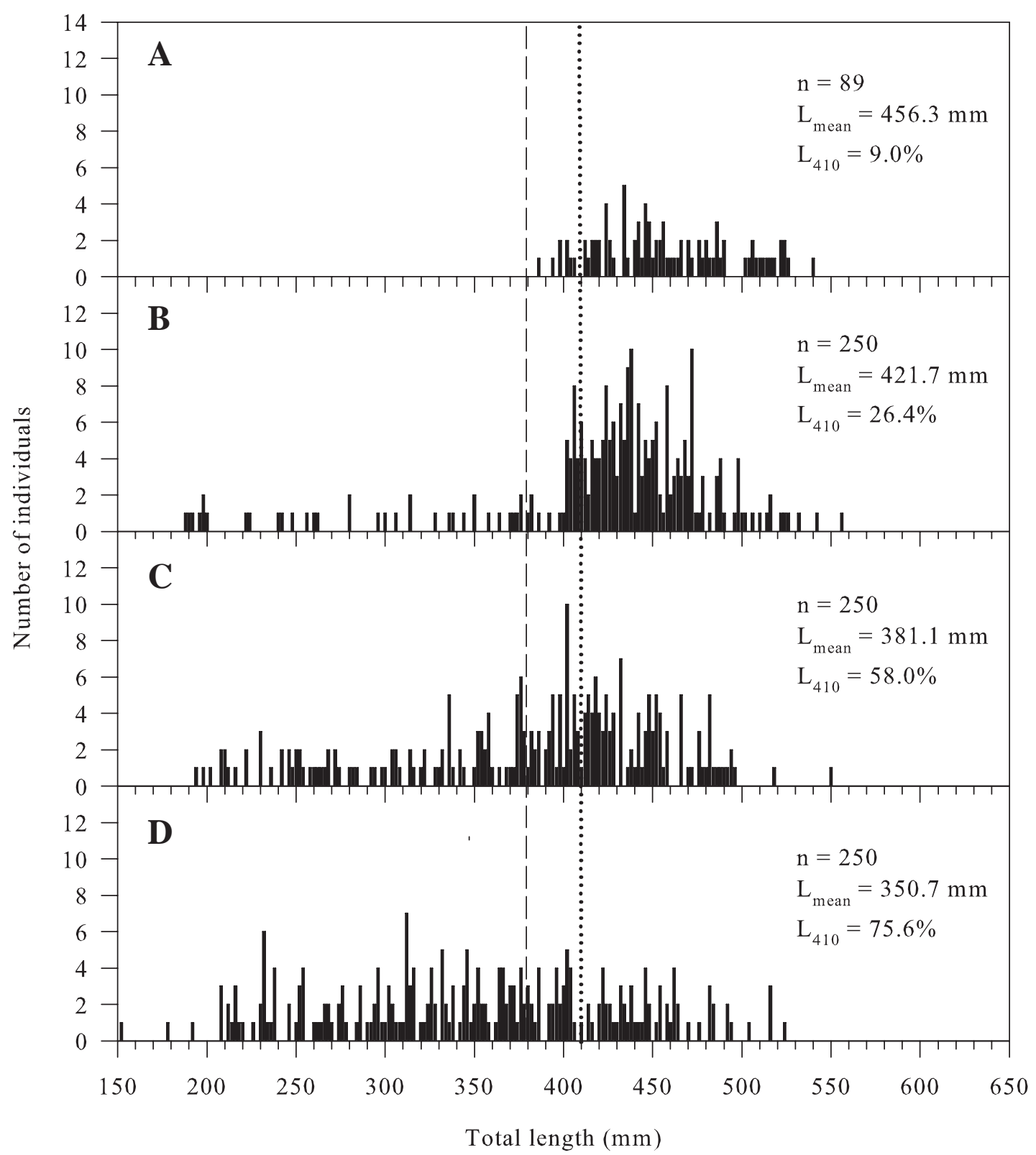

Fig. 8. Atlantic hagfish length-frequency distribution by trap type: (A) $14.3 \mathrm{~mm}$, (B) $13.5 \mathrm{~mm},(\mathbf{C}) 12.7 \mathrm{~mm}$, and (D) no (control) escape holes. Traps were fished on the southwest slope of the Grand Bank at a depth of $146 \mathrm{~m}$. Dashed vertical line represents the length $(378 \mathrm{~mm})$ at $50 \%$ sexual maturity in females, while the dotted vertical line represents the minimum marketable body length. Number of fish examined $(n)$, mean total length $\left(L_{\text {mean }}\right)$, and the proportion of undersized individuals $\left(L_{410}\right)$ are illustrated in each panel.

significant difference in average individual body length in the test traps $\left(F_{2} ; 586=47.85, P<0.0001\right)$ and a post hoc test of truly significant differences (Games-Howell) indicated a significant increase in average body length with each increase in escape hole size (i.e. $12.7 \mathrm{~mm} \times$ $13.5 \mathrm{~mm}, P<0.0001 ; 12.7 \mathrm{~mm} \times 14.3 \mathrm{~mm}, P<0.0001$; $13.5 \mathrm{~mm} \times 14.3 \mathrm{~mm}, P<0.0001)$.
Capture rates in the 384-457 $\mathrm{m}$ and 591-664 $\mathrm{m}$ depth intervals varied substantially both within and among trap types (Table 1). Two-way analyses of variance indicated average capture rates, expressed as number/hour and $\mathrm{kg} /$ hour, did not differ significantly among test traps set at the same depth interval nor between similar test traps set at different depths (Table 2). These analyses suggest 
TABLE 2. Results of two-way analyses of variance comparisons of Atlantic hagfish catches by test trap and depth.

\begin{tabular}{lrrrrr}
\hline \hline Source & df & SS & MS & $F$ & $P$ \\
\hline Number/hour & & & & & \\
Trap & 1 & 56.5 & 56.5 & 1.75 & 0.210 \\
Depth & 2 & 67.3 & 33.6 & 1.04 & 0.382 \\
Trap $\times$ Depth & 2 & 100.4 & 50.2 & 1.56 & 0.251 \\
Error & 12 & 386.9 & 32.2 & & \\
Total & 17 & 611.1 & & & \\
Kilograms/hour & & & & & \\
Trap & 1 & 0.29 & 0.29 & 0.89 & 0.365 \\
Depth & 2 & 1.16 & 0.58 & 1.78 & 0.210 \\
Trap $\times$ Depth & 2 & 0.44 & 0.22 & 0.67 & 0.528 \\
Error & 12 & 3.91 & 0.32 & & \\
Total & 17 & 5.79 & & & \\
\hline
\end{tabular}

increasing the escape hole size to avoid capturing large quantities of juvenile and undersized hagfish will not significantly influence the average capture rates within the 384-664 m depth interval. Similar and somewhat lengthy (33.0-34.5 hour) soak times and a reduction in the overall proportion of small hagfish at these depth intervals (Fig. 7) may account for the similarity in average capture rates. However, it is important to note the analyses were based on catches in a small number of traps and confidence in the conclusions would increase with a larger sample size.

Undersized hagfish accounted for a similar percentage of the catch in the $12.7 \mathrm{~mm}$ and $13.5 \mathrm{~mm}$ test traps at both the 384-457 $\mathrm{m}$ and 591-664 $\mathrm{m}$ depth intervals (Fig. 9 and 10). The $14.3 \mathrm{~mm}$ trap captured the lowest percentage of undersized hagfish at both depth intervals and average body length was also greater in the $14.3 \mathrm{~mm}$ trap (Fig. 9 and 10). A one-way analysis of variance indicated there was no significant difference in average individual body length among test traps in the 384-457 $\mathrm{m}$ depth interval $\left(F_{2} ; 532=2.32, P=0.099\right)$, but average body length did differ significantly among test traps in the 591-664 m depth interval $\left(F_{2} ; 747=16.42, P<0.0001\right)$. A post hoc test of truly significant differences (GamesHowell) revealed a significant difference in average body length among all test traps fished at the 591-664 m depth interval (i.e. $12.7 \mathrm{~mm} \times 13.5 \mathrm{~mm}, P=0.022 ; 12.7 \mathrm{~mm}$ $\times 14.3 \mathrm{~mm}, P=0.008 ; 13.5 \mathrm{~mm} \times 14.3 \mathrm{~mm}, P<0.0001)$.

The largest hagfish examined from the test traps over all depths sampled measured $646 \mathrm{~mm}$ TL. Diameter of the trap funnel entrance did not bias the maximum length of hagfish captured. Hagfish of a size suitable for leather production ( $>500 \mathrm{~mm}$ TL) were poorly represented in both the control and test traps (Fig. 8-10).

\section{Predicted Levels of Discarding in a Commercial Fish- ery}

Atlantic hagfish discarded in fisheries off the east coast of the United States are likely to die when returned to the relatively warm and low saline surface waters (Adam and Strahan, 1963; Martini, 1998a). To better illustrate the potential level of discarding of undersized hagfish in a Grand Bank fishery, the test trap catch data and length-weight relationship were used to generate estimates of the catch in kilograms of undersized and market sized hagfish in a fleet of 30 traps (Table 3 ). The results suggest about 6.43 metric tons (mt) of Atlantic hagfish could be captured in a fleet of $12.7 \mathrm{~mm}$ traps set at the $146 \mathrm{~m}$ depth interval, but because $58 \%$ of the catch was undersized, about $3.73 \mathrm{mt}$ would be discarded. Thus, for every mt of market-sized hagfish landed in the $12.7 \mathrm{~mm}$ traps, $1.38 \mathrm{mt}$ of undersized hagfish would be discarded. This coincides with an undersized by-catch of $138 \%$. A comparison across all depths and trap types indicates the lowest level of discarding, and hence greatest conservation of the resource, would be achieved by utilizing traps with $14.3 \mathrm{~mm}$ escape holes (Table 3). Bycatch of undersized hagfish in the $14.3 \mathrm{~mm}$ traps ranged from lows of $10-16 \%$, while by-catch in the $12.7 \mathrm{~mm}$ and $13.5 \mathrm{~mm}$ traps ranged from $36-138 \%$.

\section{By-catch of Non-Targeted Species}

The snubnose eel (Simenchelys parasiticus) was the only species of fish captured incidentally during this study. Three snubnose eels measuring 189-259 mm TL were captured in traps fished at the 384-457 $\mathrm{m}$ depth interval, while seven individuals measuring 222-344 mm TL were captured in the 591-664 m depth interval. Scott and Scott (1988) indicate this species is of no economic importance and describe it as a bottom-living fish inhabiting depths of 366-1 $645 \mathrm{~m}$ or more along the continental slope and offshore banks of the western North Atlantic. The snubnose eel is reported to be partly parasitic, burrowing into the flesh of halibut and other large fishes, but also lives independently on the ocean floor and is assumed to consume dead fish and invertebrates (Scott and Scott, 1988). Capture of the snubnose eel in baited traps confirms a scavenging behaviour.

\section{Discussion}

This is the first study to establish a maturity ogive for female Atlantic hagfish and demonstrated about $80 \%$ of the females in the Newfoundland Grand Bank 


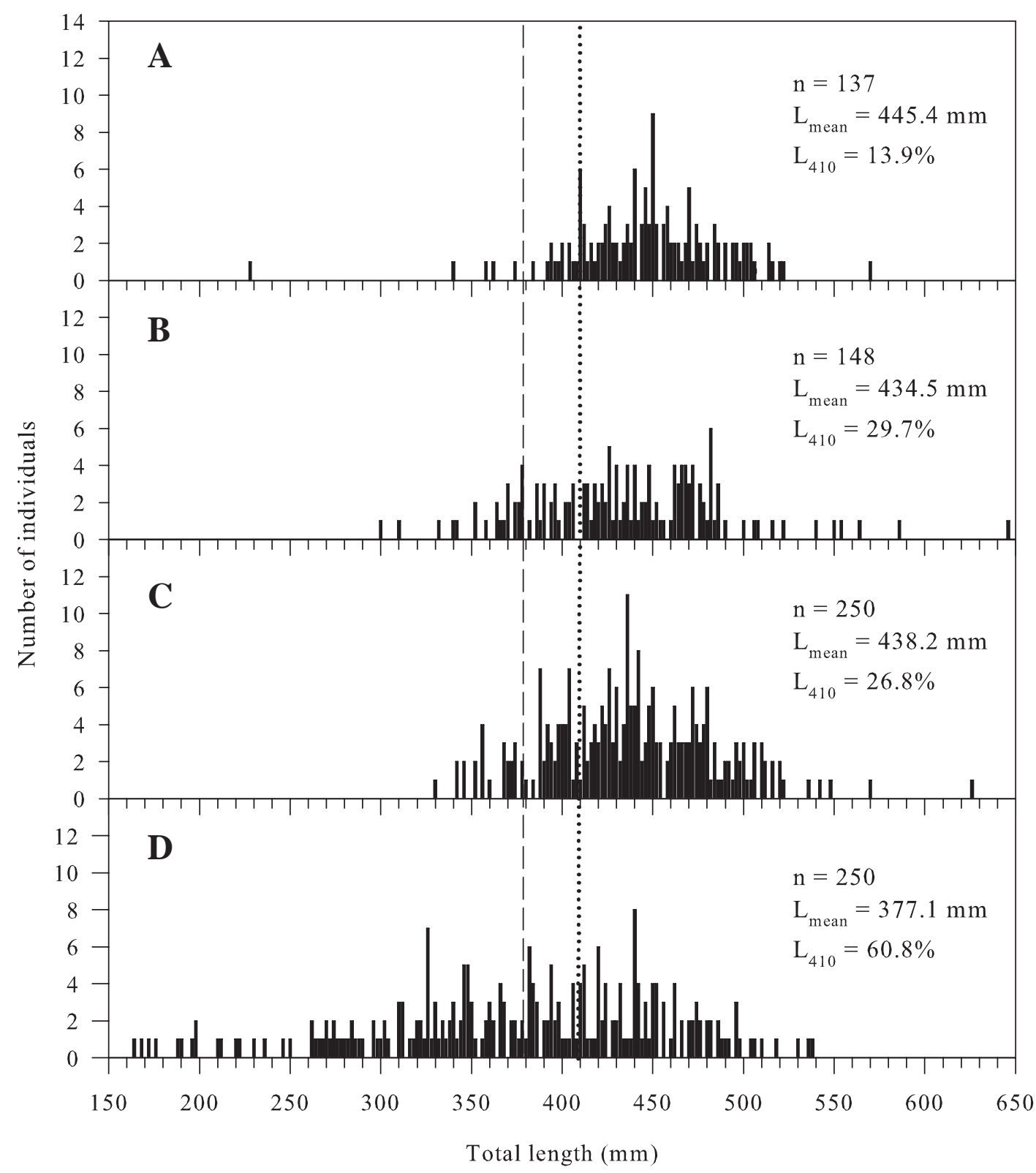

Fig. 9. Atlantic hagfish length-frequency distribution by trap type: (A) $14.3 \mathrm{~mm},(\mathbf{B}) 13.5 \mathrm{~mm},(\mathbf{C}) 12.7 \mathrm{~mm}$, and (D) no (control) escape holes. Traps were fished within a depth interval of 384-457 $\mathrm{m}$ on the southwest slope of the Grand Bank. Vertical lines and text as in Fig. 8.

population attain sexual maturity at the minimum size accepted by foreign markets in 2002. Fisheries management plans that consider this life history characteristic can play an important role in the long-term sustainability of the resource by setting minimum size limits that provide an opportunity for a suitable proportion of females to spawn at least once prior to capture. However, given the high susceptibility of undersized hagfish to capture in baited traps and uncertainty surrounding the survival of discarded hagfish (Adam and Strahan, 1963; Martini, 1998a), it is equally important there be a concerted effort to avoid the capture and handling of juveniles and undersized individuals.

Comparable to values reported elsewhere (Walvig, 1963; Patzner, 1982), the low reproductive potential of Grand Bank Atlantic hagfish indicates a high susceptibility to over-exploitation from intensive fishing pressure. The positive correlations between fecundity and body length are a new finding for this species and 


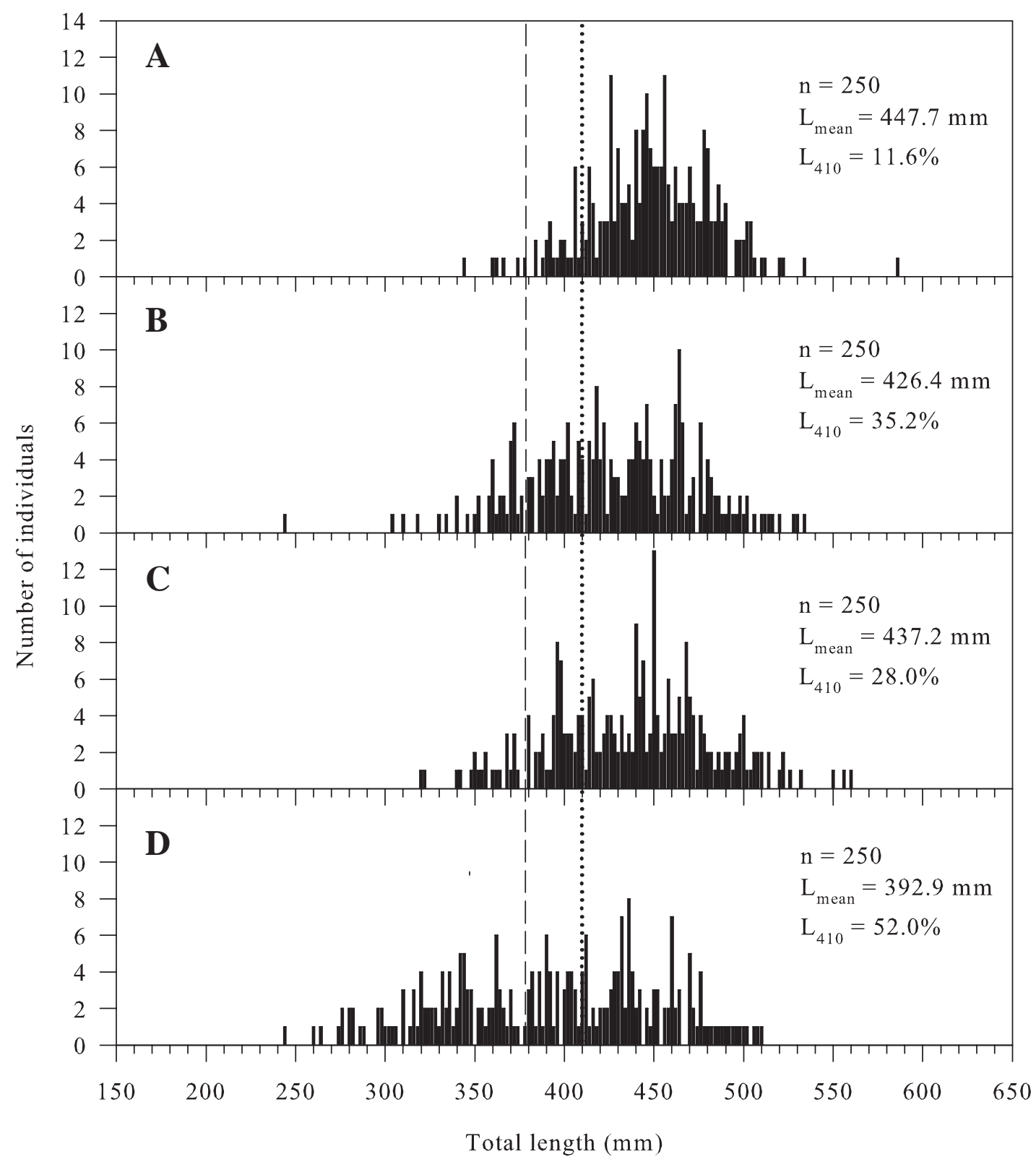

Fig. 10. Atlantic hagfish length-frequency distribution by trap type: (A) $14.3 \mathrm{~mm}$, (B) $13.5 \mathrm{~mm}$, (C) $12.7 \mathrm{~mm}$, and (D) no (control) escape holes. Traps were fished within a depth interval of 591-664 $\mathrm{m}$ on the southwest slope of the Grand Bank. Vertical lines and text as in Fig. 8.

indicate larger adult females captured during autumn have a greater capacity to contribute to population growth than smaller adults. The current study corroborates findings in the eastern North Atlantic (Lyngnes, 1931, 1936) that showed the number of developing eggs present in the ovaries of Atlantic hagfish at the beginning of the reproductive cycle is not a reliable indicator of the number of eggs released during spawning. However, differences in egg degeneration were apparent among eastern and western North Atlantic populations. Degenerated eggs were found throughout the reproductive cycle of hagfish examined from the eastern North Atlantic and the degeneration percentage was high until the developing eggs attained a length of $17 \mathrm{~mm}$ (Lyngnes, 1936). The degeneration percentage was considerably lower in Grand Bank hagfish and degenerated eggs were found only in the early stage of the reproductive cycle among females with developing eggs that were less than $12 \mathrm{~mm}$ 
TABLE 3. Summary of predicted Atlantic hagfish catches $(\mathrm{kg})$ in a fleet of 30 traps.

\begin{tabular}{lrrr}
\hline \hline & \multicolumn{3}{c}{ Depth interval (m) } \\
\cline { 2 - 4 } Catch data & \multicolumn{1}{c}{146} & $384-457$ & $591-664$ \\
\hline 12.7 mm escape holes & 6429 & 1224 & 252 \\
Total & 3729 & 328 & 71 \\
Undersized & 2700 & 896 & 181 \\
Market sized & $138.1 \%$ & $36.6 \%$ & $39.2 \%$ \\
By-catch of undersized & & & \\
13.5 mm escape holes & 3,177 & 297 & 312 \\
Total & 839 & 88 & 110 \\
Undersized & 2338 & 209 & $54.5 \%$ \\
Market sized & $35.9 \%$ & $42.1 \%$ & \\
By-catch of undersized & & & 378 \\
14.3 mm escape holes & 747 & 429 & 44 \\
Total & 67 & 60 & 334 \\
Undersized & 680 & 369 & $13.2 \%$ \\
Market sized & $9.9 \%$ & $16.2 \%$ & \\
By-catch of undersized & & & \\
\hline
\end{tabular}

in length. These differences are not surprising as studies in the eastern North Atlantic identified the importance of season and location on the degeneration percentage (Lyngnes, 1931), which is suggestive of local environmental effects. In addition to body length, latitudinal differences in annual water temperature, length of the growing season, and food availability are likely to influence the percentage of eggs reaching maturity and the overall reproductive potential of a population.

The liver appears to be an energy storage organ in Atlantic hagfish as the ripening of eggs and production of large amounts of yolk has been shown to depend on the hepatosomatic index (Patzner and Adam, 1981). Food availability influences liver energy reserves in fish and periods of under nutrition have been shown to not only reduce the hepatosomatic index (Black and Love, 1986; Grant and Brown, 1999), but also the number of yolked eggs by atresia in females maturing to spawn (Mehsin, 1981; Kjesbu et al., 1991). Thus, degeneration and atretic resorption of a proportion of a maturing clutch of eggs by Atlantic hagfish appears to represent an adaptive strategy that offsets a decrease in nutritional condition resulting from low food availability, but still allows a proportion of the clutch to reach maturity. Egg loss to atresia throughout the reproductive cycle by eastern North Atlantic populations of Atlantic hagfish (Lyngnes, 1931, 1936) is suggestive of irregular feed- ing and a continuous need to realign the fecundity to local environmental conditions. Moreover, egg degeneration throughout the reproductive cycle and inclusion of females with eggs as small as $11 \mathrm{~mm}$ may explain why Patzner (1982) did not find a correlation between fecundity and body length in a population of Atlantic hagfish examined from the eastern North Atlantic. In the Grand Bank population, the fecundity-body length correlation was strongest among females that possessed developing eggs from the largest egg length mode and these females did not possess degenerating eggs. It is unclear why degenerating eggs were found only in the very early stage of the reproductive cycle of the Grand Bank population. Future studies should not only consider whether seasonal and year-to-year differences in energy reserves influence recruitment to the maturing clutch of eggs, but also how energy reserves influence the degeneration percentage throughout the reproductive cycle.

Capture of female Atlantic hagfish with eggs in all stages of development and females with large ovulated follicles in autumn, winter, and summer in the eastern North Atlantic led Cunningham (1886) and Nansen (1887) to conclude spawning is not limited to any particular season. Patzner (1982) examined four stages in the reproductive cycle of female Atlantic hagfish from the eastern North Atlantic during the spring of three different years and after finding no evidence of a dominant stage 
concluded there was no synchronous reproductive cycle. However, recent studies provide evidence of a seasonal reproductive cycle in the western North Atlantic (Powell et al., 2004), while the bimodal egg length-frequency distribution presented in the current study combined with the presence of several females with postovulatory follicles suggests there may be two to three synchronized spawning events per year on the Grand Bank and emphasize the need to revisit past methodologies used to elucidate the nature of the reproductive cycle in Atlantic hagfish. Indeed, a more recent study of sexual maturity of Atlantic hagfish, which included an examination of over 3000 individuals collected from 11 widely spaced depth stratified sampling stations on the Grand and St. Pierre Banks, not only verified the bimodal egg-length frequency distribution was wide spread and repeated from year-to-year, but also identified a synchronized spawning (ovulatory) event (S. Grant, in prep). It is unclear whether the bimodal egg-length frequency distribution is unique to the Newfoundland region. The modality of the egg-length frequency distribution and presence of females with postovulatory follicles suggests the duration of the reproductive cycle and spawning season(s) can be resolved by periodic sampling (e.g. monthly) and tracking of the modal shift in egg length classes and the occurrence and degeneration of postovulatory follicles. Moreover, periodic sampling and assessment of sexual maturity stages is the standard practice used to elucidate the reproductive cycle of fish. Two co-occurring spawning populations of Atlantic herring (Clupea harengus), distinguished by distinct spawning seasons, have been well documented for the Newfoundland and Labrador region (Hodder, 1972) and when spawning activity was observed throughout the year in Greenland halibut (Reinhardtius hippoglossoides) from the Flemish Pass, it was periodic sampling and a detailed analysis of sexual maturity that identified two spawning peaks in a single year (Junquera and Zamarro, 1994). Similar findings of two spawning peaks in a single year have also been reported for Greenland halibut from the eastern North Atlantic (Fedorov, 1971).

The capture of male Atlantic hagfish with almost mature sperm in all seasons (Nansen, 1887) has also been interpreted to provide evidence of no particular spawning season. However, compared to eggs, sperm represent a very minor cytoplasmic investment, particularly in hagfish, and in teleosts that exhibit distinct spawning seasons, it is not uncommon for fully developed sperm to be present throughout the year in some species while in others sperm is present weeks to months prior to the spawning season and residual sperm may also be found for months after spawning (Templeman, 1948; Henderson, 1962; Pitt, 1966; Falk-Petersen and Hansen, MS
1991; Moulton and Burton, 1999; Stoner et al., 1999). Thus, it would appear the capture of male Atlantic hagfish with maturing sperm throughout the year does not rule out the possibility of two or more synchronized spawning events in a single year.

In the current study, the next clutch of eggs was developing in over $50 \%$ of the females that possessed postovulatory follicles, a result that contrasts findings in the Gulf of Maine (Martini et al., 1997a). Lack of eggs in advanced stages of development in hagfish with postovulatory follicles led Martini et al. (1997a) to conclude there must be a significant time period between reproductive cycles in the Gulf of Maine. Martini et al. (1997b) also commented on the lack of gonadal development in $25 \%$ of the animals examined $>400 \mathrm{~mm}$ TL and small number of gravid $(<1 \%)$ and postovulatory $(<5 \%)$ females, which also contrasts the current findings for the Grand Bank. Although some of these characteristics may be influenced by capture season, together the higher percentage of gravid and postovulatory females, low number of hagfish exhibiting a lack of gonadal development once they attained the length at sexual maturity, short time period between reproductive cycles, and bimodal egglength frequency distribution suggests a greater overall reproductive potential of Grand Bank Atlantic hagfish.

There was an unequal sex ratio in the Grand Bank population as there were no Atlantic hagfish that could be definitively described as males, maturing or otherwise. It is unclear whether lack of testis maturation is related to sampling outside the spawning season or whether several of the sexually indeterminate hagfish would ultimately become functional females. Walvig (1963) and others (Martini et al., 1997a; Patzner, 1998) indicate the unequal sex ratio of far more females than males is common in Atlantic hagfish, but Walvig (1963) also summarizes cases where males were plentiful. From these findings, it seems reasonable to speculate that in some populations the sexes are geographically separate during certain times of the year (Holmgren, 1946). Marked Atlantic hagfish have been reported to move short distances (Walvig, 1963, 1967), which led Walvig (1967) to speculate Atlantic hagfish could perform regular short migrations for spawning and the Japanese hagfish is known to migrate into deeper water prior to spawning (Kobayashi et al., 1972). Holmgren (1946) and Walvig (1963) also speculated that an inability to capture males maturing to spawn and females in spawning condition in baited traps is due to an adaptive loss of feeding behaviour before breeding. Ultimately, there is a clear need for more studies on the geographic distribution and movements of the sexes in Atlantic hagfishes and partnering among scientists and fishermen during the commercial 
development of a virgin stock would provide an unique opportunity to not only address these characteristics, but also to better understand growth, sex differentiation, the reproductive cycle, spawning, and how populations respond to a fishery.

A comparison of Atlantic hagfish from the western and eastern North Atlantic led Wisner and $\mathrm{M}^{\mathrm{c}}$ Millan (1995) to propose elevating the former to distinct species status. Their conclusions were based on contrasting body coloration and markings of preserved material, differing maximum body length, and size at first attainment of sexual maturity. Eastern North Atlantic hagfish exhibit a uniform grayish-pink coloration on the lateral and dorsal aspect of the body, attain a maximum body length of 450 $\mathrm{mm}$, and females first attain sexual maturity at $320 \mathrm{~mm}$ TL (Cunningham 1886; Adam and Strahan 1963; Wisner and McMillan 1995). The 139 specimens of western North Atlantic hagfish available to Wisner and $\mathrm{M}^{\mathrm{c}}$ Millan (1995) ranged from as far north as the Davis Strait to Florida in the south and included $36(26 \%)$ individuals collected from the Grand Bank in the 1960s and 1970s. All hagfish examined from the western North Atlantic were reported to exhibit a reddish-brown to blackish-purple coloration. 'Most' of the western North Atlantic material exhibited a narrow pale streak along the dorsal midline, extending forward from the caudal finfold an average of $46 \%(18-80 \%)$ of the TL. The longest western North Atlantic hagfish examined by Wisner and McMillan (1995) was $510 \mathrm{~mm}$ TL and a maximum length record of $950 \mathrm{~mm}$ was recorded from the Gulf of Maine (Martini et al., 1998). The shortest female to possess large eggs from the western North Atlantic was $368 \mathrm{~mm}$ TL (Wisner and $M^{\mathrm{C}}$ Millan, 1995) and a more recent study in the Gulf of Maine (Martini et al., 1997a) concluded females do not attain sexual maturity until they are $>400 \mathrm{~mm}$ TL. However, few $(<10 \%)$ of the 122 hagfish examined from the Gulf of Maine were $<400 \mathrm{~mm}$ TL.

All of the Atlantic hagfish examined in the current study were collected within $25 \mathrm{~km}$ of the Grand Bank samples examined by Wisner and McMillan (1995) yet they invariably exhibited a pinkish-gray body coloration similar to that described for populations in the eastern North Atlantic, even after up to 24 months in preservative. In addition, in 2004 over $100 \mathrm{mt}$ of Atlantic hagfish were harvested along the southwest slope of the Grand Bank during an exploratory fishery that encompassed an area of over $2000 \mathrm{~km}^{2}$. Harvesters and fisheries observers alike commented on the invariable pinkish-gray body coloration of these hagfish. These observations are surprising given the invariable reddish-brown to blackish-purple coloration previously described for preserved specimens from the Grand Bank region and the western North Atlantic as a whole (Wisner and McMillan, 1995). However, body coloration is a highly variable and subjective taxonomic characteristic in fish and body color can also be influenced by the method and duration of preservation and storage. Recent laboratory examination of well over 10000 Atlantic hagfish captured on the Grand and St. Pierre Banks appears to provide some insight into the contrasting coloration described for this species. Somewhat serendipitous was my discovery that when previously frozen Atlantic hagfish were exposed to air the body developed a reddish-brown coloration similar to that described by Wisner and McMillan (1995). Thus, body coloration of Atlantic hagfish may also be influenced by how they are treated prior to preservation. Effects of preservation on the coloration of hagfish exposed to air were not investigated.

The current study corroborates Wisner and McMillan's (1995) findings on the greater maximum body length and corresponding greater female length at first attainment of sexual maturity of western North Atlantic hagfish and there is evidence to suggest at the population level an increase in maximum length leads to a thinner less robust body form (Martini et al., 1998). A high proportion of the Atlantic hagfish examined in the current study possessed a narrow pale streak along the dorsal midline but the length of the streak relative to TL was considerably shorter than that observed in Wisner and M'Millan's (1995) entire western North Atlantic sample. Wisner and M'Millan's (1995) sample was largely (68\%) comprised of animals collected from continental slope and shelf waters of the eastern US. Overall, it is conclude the characteristics examined in the current study fail to provide sufficient evidence to support elevating western North Atlantic hagfish to distinct species status. However, the intermediate position of the Grand Bank population to the eastern North Atlantic and southern populations in the western North Atlantic with regard to maximum length, size-at-maturity, and body markings suggests the existence of clinal variants as proposed by Fernholm (1998) and Martini et al. (1998).

Catches in the control traps indicate a clear and significant increase in average individual size of Atlantic hagfish with increasing depth on the southwest slope of the Grand Bank. This size and depth related distribution might reflect a gradual movement of larger hagfish to deeper slope waters as they grow to maturity or, as Walvig (1963) suggested, a movement by adults as they mature to spawn. Conversely, the prevalence of small Atlantic hagfish in relatively shallow waters of the Grand Bank suggests a greater affinity for shallow water areas. 
This study shows juveniles are highly susceptible to trap fisheries and if shallow water areas represent nursery and rearing grounds, then hagfish fisheries should take precautions to avoid incidental catches and over fishing of juveniles in these areas.

Atlantic hagfish prefer muddy bottoms (Patzner, 1998) and the prevalence of this habitat type on the southwest slope of the Grand Bank and associated deepwater channels combined with the capture rates observed in this study suggest harvestable quantities of Atlantic hagfish occur within the 384-457 m and 591-664 m depth intervals. Although capture rates were promising, too few traps were assessed to provide a valid estimate of the relative abundance of hagfish in the $146 \mathrm{~m}$ depth interval. The catch was not assessed at the 245-293 m depth interval due to decomposition, however, the traps were full suggesting harvestable quantities also occur at this depth interval. Undersized hagfish consistently accounted for the lowest percentage of the catch in the $14.3 \mathrm{~mm}$ traps and when data were extrapolated to commercial catches it was apparent the $14.3 \mathrm{~mm}$ trap provided the greatest potential for conservation of the resource by limiting the catch and on board handling of juveniles and undersized hagfish.

The slime secreted by hagfish expands as it absorbs seawater and Martini (1998a) suggested once hagfish entered a baited trap they could become trapped in the bait and their own slime. Trap mortalities observed in this study are attributed to a combination of insufficient escape hole size and lengthy soak time, which appear to have led to overcrowding, the secretion of slime, and suffocation of a portion or all of the catch. Soak times of 12-24 hours have been recommended for Atlantic hagfish (DFO, 1993) because in Pacific Ocean fisheries larger hagfish are captured in these soaks compared to shorter, four- to eight-hour soak times. Decomposition of the entire catch during a 50-hour soak time in the current study demonstrates lengthy soaks are unsuitable in an Atlantic hagfish fishery and available evidence suggests every effort should be made to haul traps within 24-34 hours.

In early development, many fisheries have expanded at the pace of man's desire for fish rather than based on a priori consideration of what level of removals the resource might absorb (Atkinson, 1995). Here, 'removals' are considered to include undersized individuals captured incidentally while in pursuit of the market or legal sized fish. Unfortunately, much of the scientific information required to assess the status of fish stocks is completely lacking for Atlantic hagfish. Growth rate and longevity are unknown, duration of the reproductive cycle is unclear, and there is no way to predict how a population will respond to a commercial fishery. A low reproductive potential and high susceptibility to overexploitation has been well documented for Atlantic hagfish (Scott and Scott, 1988; Homna, 1998; Martini, 1998a; Patzner, 1998; AHWG, 2003; NEFSC, 2003), while evidence of only short migrations (Walvig, 1963, 1967) suggests populations are recruitment dependent. This study demonstrated the current minimum market size would protect a great majority of juvenile Atlantic hagfish in a Grand Bank fishery, however, it was also shown that juveniles and undersized individuals are highly susceptible to capture in baited traps. There is no information on the survival capacity of discarded Atlantic hagfish in the Newfoundland and Labrador region, however, low tolerances to changes in temperature and salinity have been well documented (Adam and Strahan, 1963; Patzner, 1998) and studies conducted elsewhere suggest discard mortality in commercial fisheries may be high (Martini, 1998a). Also, difficulties with sorting of live hagfish under commercial conditions (TriNav, 1996) are likely to lead to prolonged air exposure and increased risk of mortality of discards. Fortunately, this study also demonstrated fishermen can reduce the catch of juveniles and undersized individuals simply by selecting an appropriate escape-hole size for their traps. Given the lack of information on which to base management decisions and the importance of pre-recruits to the long-term sustainability of the resource, it is recommended fishermen be encouraged to use traps with $14.3 \mathrm{~mm}$ escape holes or larger to avoid over fishing of undersized individuals.

\section{Acknowledgements}

Funding for this study was provided by the Canadian Centre for Fisheries Innovation and the Marine Institute of Memorial University of Newfoundland. The captain and crew of the Covenant II are acknowledged for their support during this study. Wade Murphy and Luiz Mello provided technical support at sea, Chris Keats and Wade Hiscock provided technical assistance during laboratory analysis and report preparation, and Paul Brett produced Fig. 1. Carole Grant, Joanne Morgan, and two anonymous reviewers provided helpful comments on an earlier version of this manuscript.

\section{References}

AHWG REPORT. 2003. review of Atlantic hagfish biological and fishery information with assessment and research considerations. A report by the Atlantic Hagfish Working Group for the New England Fishery Management Council 
May 30, 2003, 88 p.

ADAM, H., and R. STRAHAN. 1963. Notes on the habitat, aquarium maintenance, and experimental use of hagfishes. In: The biology of Myxine. A. Brodal and R. Fange (eds.). Universitetsforlaget, Oslo, p. 33-41.

ATKINSON, D. B. 1995. The biology and fishery of roundnose grenadier (Coryphaenoides rupestris Gunnerus, 1765) in the Northwest Atlantic. In: Deep-water fisheries of the North Atlantic Ocean Slope. A. G. Hodder (ed.). Kluwer Academic Publishers, p. 51-111.

BLACK, D., and R. M. LOVE. 1986. The sequential mobilisation and restoration of energy reserves in tissues of Atlantic cod during starvation and refeeding. J. Comp. Physiol., B156: 469-479.

CUNNINGHAM, J. T. 1886. On the structure and development of the reproductive elements in Myxine glutinosa $L$. Q. J. Micrbiol. Sci., 27: 49-76.

DFO. 1993. A report on the hagfish fishery and its relevance for Newfoundland. Industry Development Division, Department of Fisheries and Oceans, St. John's, Newfoundland, 18 p. + App.

1998. 1998/99 hagfish (Myxine glutinosa) interim conservation harvesting plan. Scotia-Fundy Fisheries Maritime Region, Department of Fisheries and Oceans, St. Andrews, New Brunswick, 7 p. + app.

FALK-PETERSEN, I-B., and T. K. HANSEN. MS 1991. Reproductive biology of wolffish Anarhichas lupus from north Norwegian waters. ICES Demersal Fish Committee, ICES C.M. Doc., No. 1991/G:14. 17 p.

FEDOROV, K. Y. 1971. The state of the gonads of the Barent Sea Greenland halibut (Reinhardtius hippoglossoides Walb.) in connection with failure to spawn. J. Ichthyol., 11: $673-682$.

FERNHOLM, B. 1998. Hagfish systematics. In: The biology of hagfishes. J. M. Jorgensen, J. P. Lomholt, R. E. Weber, and H. Malte (eds.). Chapman and Hall, London, p. 33-44.

GORBMAN, A. 1990. Sex differentiation in the hagfish Eptatretus strouti. Gen. Comp. Endocrin., 77: 309-323.

GRANT, S. M., and J. A. BROWN. 1999. Variation in condition of coastal Newfoundland 0-group Atlantic cod (Gadus morhua): field and laboratory studies using simple condition indices. Mar. Biol., 133: 611-620.

HENDERSON, N. E. 1962. The annual cycle in the testis of the eastern brook trout, Salvelinus fontinalis (Mitchill). Can. J. Zool., 40: 631-641.

HODDER, V. M. 1972. The fecundity of herring in some parts of the Newfoundland area. ICNAF Res. Bull., 9: 99-107.

HOLMGREN, N. 1946. On two embryos of Myxine glutinosa. Acta Zool., 27: 1-90.

HONMA, Y. 1998. Asian hagfishes and their fisheries biology. In: The biology of hagfishes. J. M. Jorgensen, J. P. Lomholt, R. E. Weber, and H. Malte (eds.). Chapman and Hall, London, p. 45-56.

JUNQUERA, S., and J. ZAMARRO. 1994. Sexual maturity and spawning of Greenland halibut (Reinhardtius hippoglossoides) from Flemish Pass area. NAFO Sci. Coun. Studies, 20: 47-52.

KJESBU, O. S., J. KLUNGSØYR, H. KRYVI, P. R. WHT-
THAMES, and M. G. WALKER. 1991. Fecundity, atresia, and egg size of captive Atlantic cod (Gadus morhua) in relation to proximate body composition. Can. J. Fish. Aquat. Sci., 48: 2333-2343.

KOBAYASHI, H., T. ICHIKAWA, H. SUZUKI, and M. SEKIMOTO. 1972. Seasonal migration of hagfish Eptatretus burgeri. Japan. J. Ichthy., 19: 191-194.

LYNGNES, R. 1931. Über atretische und hypertorphische Gebilde im Ovarium der Myxine glutinosa L. Biologisches Zentralblatt, 51: 437-441.

1936. Rückbildung der ovulierten und nicht ovulierten Follikel im Ovarium der Myxine glutinosa L. Skrifter norske Videnskaps-Academi i Oslo l. matematisknaturvidenskapelige Klasse, 4: 1-116.

M MILLAN, C. B., and R. L. WISNER. 1984. Three new species of seven-gilled hagfishes (Myxinidae, Eptatretus) from the Pacific Ocean. Proc. Calif. Acad. Sci., 43: 249-267.

MARTINI, F. H. 1998a. Secrets of the slime hag. Scientific American, October: 70-75.

1998b. The ecology of hagfishes, In: The biology of hagfishes. J. M. Jorgensen, J. P. Lomholt, R. E. Weber, and H. Malte (eds.). Chapman and Hall, London, p. 46-77.

MARTINI, F. H., M. P. LESSER, and J. B. HEISER. 1998. A population profile for hagfish, Myxine glutinosa, in the Gulf of Maine. Part 2: Morphological variation in populations of Myxine in the North Atlantic Ocean. Fish. Bull., 96: $516-524$.

MARTINI, F. H., J. B. HEISER, and M. P. LESSER. 1997a. A population profile for the Atlantic hagfish, Myxine glutinosa (L.), in the Gulf of Maine. Part 1: Morphometrics and reproductive state. Fish. Bull., 95: 311-320.

MARTINI, F. H., M. LESSER, and J. B. HEISER. 1997b. Ecology of the hagfish, Myxine glutinosa L., in the Gulf of Maine: 2. Potential impact on benthic communities and commercial fisheries. J. Exp. Mar. Biol. Ecol., 214: 97-106.

MEHSIN, K. A. A. 1981. Some effects of food supply on the annual cycle of female Phoxinus phoxinus, $\mathrm{PhD}$ Thesis, University of Wales.

MOULTON, S. A., and M. P. M. BURTON. 1999. Histological observations on spermatogenesis in winter flounder, Pleuronectes americanus Walbaum, from Conception Bay, Newfoundland, Canada. Can. J. Zool., 77: 1682-1689.

NANSEN, F. 1887. A protandric hermaphrodite (Myxine glutinosa L.) amongst the vertebrates. Bergen Mus. Aarsber., $1-34$.

NEFSC. 2003. Atlantic hagfish. In: Report of the $37^{\text {th }}$ Northeast Regional Stock Assessment Workshop (37 $7^{\text {th }}$ SAW): Stock Assessment Review Committee (SARC) consensus summary of assessments. NFSC Ref. Doc., No. 03-16, p. 518-597.

PATZNER, R. A. 1982. Die Reproduktion der Myxinoiden. Ein Vergleich von Myxine glutinosa und Eptatretus burgeri. Zoologischer Anzeiger (Jena), 208: 132-144.

1998. Gonads and reproduction in hagfishes. In: The biology of hagfishes. J. M. Jorgensen, J. P. Lomholt, R. E. Weber, and H. Malte (eds.). Chapman and Hall, 
London, p. 378-379.

PATZNER, R. A., and H. ADAM. 1981. Changes in weight of the liver and the relationship to reproduction in the hagfish Myxine glutinosa (Cyclostomata). J. Mar. Biol. Assoc. (UK), 61: 461-464.

PITT, T. K. 1966. Sexual maturity and spawning of the American plaice, Hippoglossoides platessoides (Fabricius), from Newfoundland and Grand Banks areas. J. Fish. Res. Board. Can., 23: 651-672.

POWELL, M. L., S. I. KAVANAUGH, and S. A. SOWER. 2004. Seasonal concentrations of reproductive steroids in the gonads of the Atlantic hagfish, Myxine glutinosa. J. Exp. Zool., 301A: 352-360.

SCHREINER, K. E. 1955. Studies on the gonad of Myxine glutinosa L. Universitet I Bergen, Arbok 1955, Naturvit. Rekke, 8: 1-40.

SCOTT, W. B., and M. G. SCOTT. 1988. Atlantic fishes of Canada. Can. Bull. Fish. Aquat. Sci., 219: 731 p.

STONER, A. W., A. J. BEJDA, J. P. MANDERSON, B. A. PHELAN, L. L. STEHLIK, and J. P. PESSUTTI. 1999. Behavior of winter flounder, Pseudopleuronectes ameri- canus, during the reproductive season: laboratory and field observations on spawning, feeding, and locomotion. Fish. Bull., 97: 999-1016.

TEMPLEMAN, W. 1948. The life history of capelin (Mallotus villosus O. F. Müller) in Newfoundland waters. Bull. Newfoundland Govt. Lab., 17: 151 p.

TRINAV. 1996. A report on the project to investigate the potential of developing an Atlantic hagfish fishery on the southwest coast of Newfoundland Final report (Phase I and Phase II). Report submitted to the Canada/Newfoundland Cooperation Agreement for Fishing Industry Development, 21 p. + App.

WALVIG, F. 1963. The gonads and the formation of the sex cells. In: The biology of Myxine. A. Brodal and R. Fange (eds.). Universitetsforlaget, Oslo, p. 530-580.

1967. Experimental marking of hagfish (Myxine glutinosa L.). Norw. J. Zool., 15: 35-39.

WISNER, R. L., and C. B. MCMILLAN. 1995. Review of new world hagfishes of the genus Myxine (Agnatha, Myxinidae) with descriptions of nine new species. Fish. Bull., 93: $530-550$. 